\title{
THE FILM-INDUCED TOURISM DEVELOPMENT IN BRUNEI: PERSPECTIVES AND POTENTIALITY
}

\author{
${ }^{1}$ Wei Lee Chin* and ${ }^{2}$ Yong Liu** \\ ( ${ }^{*}$ First author, ${ }^{* *}$ Corresponding author) \\ ${ }^{1}$ Department of Geography, Environment and Development \\ ${ }^{2}$ Department of Design and Creative Industries \\ Faculty of Arts and Social Sciences \\ Universiti Brunei Darussalam \\ (Weilee.chin@ubd.edu.bn, yong.liu@ubd.edu.bn ) \\ DOI: https://doi.org/10.22452/brj.vol12no1.3
}

\begin{abstract}
Film has been the main medium for accessing the mass population that can play a significant role in influencing travel or tourist decision making. It is argued that film-induced tourism delivers a permanent image of the destination and could be a more economical strategy for destinations to promote themselves. This paper, therefore, looks at the potentiality of film-induced tourism in Brunei. This paper will illustrate case studies, e.g. Matamata, a small town in New Zealand from Peter Jackson's The Hobbits trilogy, that have made it a popular tourist destination that attracts travelers from around the world. Furthermore, local Bruneian films such as Ada Apa Dengan Rina, Rina 2 as well as a horror trilogy made by Tutong-based filmmaker Abdul Zainidi will also be discussed. This paper will explore whether Bruneian local production films trigger any interests in visiting the film's portrayed locations and whether filming in a certain attraction has different impacts on tourists' decision making. In addition, based on a survey and semistructured interviews, this paper will also investigate if film genre or character/story affects the typology of tourists to understand the connection between the tourism and film industry better. Analysis of this study will be twofold: one from data collection while the other from textual analysis.
\end{abstract}

Keywords: film tourism, destination marketing, film production, emerging tourism 


\section{Introduction}

Film has been the main medium for accessing the mass population that can play a significant role in influencing travel or tourist decision making. With the proliferation of international visitors and the increasing significance in the entertainment industry, film-induced tourism is becoming recognizable. Visitors are faced with countless destinations to choose from. Hence tourists need to be lured with effective marketing strategies to maintain destinations market share as well as to attract potential market segment. There are increasingly notable tourism organizations in destinations such as the United Kingdom (UK), United States of America (USA), New Zealand, Korea, Singapore and Australia who are utilizing film related traits as marketing opportunities. Furthermore, it is argued that filminduced tourism delivers a more viable and permanent image of the destination thus could be a more economical strategy for struggling destinations to promote themselves. Images play a massive role in determining potential tourists' decision to visit a particular destination. Despite the growing interest, an understanding of film-induced tourism in Brunei is extremely limited. This paper, therefore, explores the relations between film and tourism and whether local produced films have triggered any interests in visiting the film's portrayed locations. This paper will also investigate if film genre or character/story affects tourists' decision making in order to better understand the connection between the film and tourism industry.

\section{Literature Review}

Referring to Connell, "film tourism is tourist activity induced by the viewing of a moving image, and is accepted as encompassing film, television, pre-recorded products (e.g., Video/DVD/Blue-RAY)... and now extends to digital media" (2012, p. 1109). While other terms have been introduced in tourism research such as movie tourism (used interchangeably with film tourism), screen tourism, film tourism seems to be the most popular term used in majority of the studies. There have been a number of debates on the comprehensiveness of each above term but arguably "the term is less important than the concept" (Connell, 2012, p. 1109). Although we prefer to use "screen tourism", as the term may include all forms of moving image in all digital forms (film, television, video, DVD and Blue-RAY are all played on a certain form of screen in digital age), we would be happier to adopt film-induced tourism in this paper, as the term more narrowly defines that "tourist visits are induced or stimulated by viewing a film location on-screen" (Connell, 2012, p. 1109). Besides, our emphasis in this paper will be focused on the 
perspectives from both the demand-side (tourists) and the supply-side (filmrelated tourist locations).

The evolution of tourist needs, the new marketing channel or the emerging innovative trends has always kept the priorities of the tourism board or destination management organizations (DMOs) in a constant state of flux. The shift in demand to search for new destination and experiences beyond traditional forms seems to be the contemporary preference for tourists. This has been supported by a number of research such as Park and Santos (2017) and Kim and Ritchie (2014) who studied on understanding memorable tourism experiences; Rewtrakunphaiboon (2009) studying on inventing a vacation to a location; and Scott, Laws and Boksberger (2010) on exploring the incorporating of experiences into products through marketing a destination.

Film-induced tourism has become popular along with the growth of entertainment as well as the travel industry (Hudson \& Ritchie, 2006). Film can provide information such as the culture and people of the destination; provide familiarity of the environment; set a scene of a particular destination, which uncovers the destination features and aspects that might create a favorable destination image. This will, in turn, have a positive impact on destination choices due to the inseparable feature of destination image and tourist decision making. Rewtrakunphaiboon (2009) study has found that film can convince viewers to visit a destination and can be a pull factor due to its influential narrations and the emotional attachment that film can portray. The reproduction of famous scenes by tourists is a common behaviour in filmed locations. One example is the American TV sitcom Friends, which started broadcasting in the 1990s and had lasted for ten seasons shooting in Manhattan, New York City. These series revolve around a group of friends often hanging out at a coffee shop named Central Perk showing lifestyle as an attractive young New Yorker. To commemorate the $20^{\text {th }}$ anniversary of this sitcom, the Central Perk coffee shop opens up pop up cafes completed with the orange coach for fans and tourists to "relive" the TV series. Tourists queued up overnight for photo opportunities and a chance to hang out and to relive the popular series (Prince, 2014).

A recent example is the successful case of Crazy Rich Asian - a Hollywood romantic comedy movie released in August 2018, casting an all Asian-American actors/actresses since Joy Luck Club (1993). Since the majority of the movie was filmed in Singapore, the global success of the movie has brought the best tourist promotion to Singapore (Badalge, 2018). The production partnership between Singapore Tourism Board and Warner Bros ensures that Singapore is portrayed as an attractive tourist destination, giving millions of potential visitors a screen glimpse of Singapore. Orbitz is a leading global travel organization (owned by 
Expedia) who specializes in online booking, offering a wide range of hotels, tour packages, flights, car rentals as well as destination activities. Internet searchers from Orbitz for Singapore increase 41 percent compared to the same time in the previous year and have seen a further increase of 15 percent in a week following the premiere of Crazy Rich Asian (Hod, 2018). Singapore Tourism Board has worked collaboratively with the film industry which is claimed by Grihault (2003) as one of the effective strategies to induce film tourists. Although it is still early to quantify tourist arrivals, the case has shown notable boost in search and booking data, which reflects the trends of destination awareness and indication of interest.

Such effective strategy has been proven sustainable by the well-known case of Matamata, New Zealand and the movies made by New Zealand filmmaker Peter Jackson. From the beginning of the initiatives, New Zealand tourist agencies, local filmmakers (Peter Jackson and his Weta Digital production company) and town government have cooperated closely with each other to promote the small township's tourism in order to get the best result out of the filmmaking process, from The Lord of the Ring (TLOTR) to The Hobbits trilogy. Leotta (2011) argues, "...the prominent association between tourist activities and film gaze in the case of TLOTR/New Zealand is the result of a complex series of interconnected factors" (p. 164). It is worth noting the similar process for another successful case of a small town in Southern Sweden, Ystad, which was the central location for a detective TV drama series Wallander, and then became a popular tourist destination during the mid-2000s for Scandinavian and later international travelers (Waade, 2016). Waade claims that the development of Ystad as a screen tourism destination has been implemented by a very close co-operation between several sectors in Skåne: film and television producers, local tourist managers and local authorities, as well as Mankell, the Swedish writer who wrote the original, same-titled novel, and Yellow Bird, the Swedish production company that produced the TV series Wallander (Waade, 2016, p. 52). These two small towns' successful cases of using filmmaking locations to promote tourism provide an invaluable conceptual and methodological model for Brunei to initiate its film-induced tourism strategy. That could be a combinatorial format between governmental policy-making and the collaborative efforts from both local film production houses and tourist agencies.

According to a Borneo Bulletin report from the United Nations World Tourism Organization (UNWTO), Brunei enjoys the third fastest growth in tourist arrivals in Southeast Asia (SEA) in 2017 - the figure shows 18.3 percent increase from the previous years; in the first quarter of 2018, an increase of 4.1 percent of international tourists have arrived at the Brunei International Airport (Othman, 2018). However, the main contribution to the 4.1 percent increase is due to a 40.5 percent growth of the Far East market, while other conventional markets, e.g. 
Australia, New Zealand and ASEAN have all shown a decrease in 13.3 percent, 8.4 percent and 5.1 percent respectively (Othman, 2018). These divergent figures demonstrate the necessity of developing some new tourism products and also revamping some existing tourism strategies for Brunei to continue attracting tourists from the neighboring Southeast Asian countries and the larger AsiaPacific regions while maintaining the momentum of the fast increasing Far East market. To achieve the goal of either developing or revamping the tourism products, destination could tap into the "emerging tourism" market. King (2017) acknowledges the difficulty in defining emerging tourism and defines the concept presumably applying to "novel kinds of tourism activity" (2017, p. 8). Although film-induced tourism is not a novel concept, the research of it is comparatively new, especially in the developing world.

Brunei has a very small film industry, which has merely produced total 11 theatrical released feature films in the past five years (2013-2018). Film-induced tourism has been long overlooked because of the limited distribution and reception of Bruneian films both domestically and internationally. The research of film-induced tourism in Brunei has just initiated, if not from the scratch of this paper. Although earlier related literature are rarely seen, the power of film in motivating tourist demands and promoting destination visitation can be one of the potentially profitable benefits if being carried out properly. Our purpose, therefore, is attempting to fill the gap of the literature and prompting more indepth research in the related field. Film-induced tourism is not the traditional advertising/promotion directly related to tourism board, but it might be an avenue where Brunei could explore. Destination image portrayed through film produces frequently retaining memory for a long period (Riley, Baker, \& Van Doren, 1998). This effect can help Brunei create exposure and destination awareness for potential tourists about where Brunei is, its culture as well as its tourism products, correcting the common misconception that Brunei is in the Middle East. The cultural aspects of the country may be vividly portrayed through the film locations, heritage sites and storylines that unfold in or around those locations.

\section{Methodology}

In order to further comprehend the opportunity of film tourism in Brunei, to determine whether film motivates people to visit a particular destination or whether the genre of films affects the perception or typology of tourists, a questionnaire survey was conducted in this study, followed by some in-depth interviews. Meanwhile, an online survey was developed to collect information relating to respondents' film viewing behaviour, their preferred genre, their 
general travel behaviour, their knowledge of local films as well as general demographic profiles. The online questionnaire consists of both open and closedended questions drawn from literature. Respondents were asked to indicate their travelling behaviour, their film viewing experiences and their reasons for travelling. Furthermore, respondents were also asked to express their reasons for positive or negative film experiences with local film productions, their thoughts on local films, as well as their views on genres and storylines of films in general.

A total of 201 questionnaires were distributed online and 18 in-depth interviews were conducted in person. The age distribution of respondents was mostly between 20-29 years and 30-39 years category. The online respondents included participants who indicated their interest in travel and film industry, making this study a purposive sample. This is done to ensure filtering of participants who are interested in film viewing and travel at the same time. Besides gathering online information, 18 in-depth interviews were also carried out to obtain more thorough information (See Table 2 in the next section for the breakdown of informants). Informants interviewed were tourists, film producers/directors, and local movie enthusiasts. This is done to get a deeper insight into Brunei film industry, its relationship with stakeholders as well as their views on how film is related to the travel industry. Then, an ensuing textual analysis was articulated in this study, hypothesizing the possibility and potentiality of Bruneian local films contributing to the tourism sector domestically and internationally. It is necessary to understand more comprehensively the network within film industry, its relationship with stakeholders in order to better grasp the current situation of the Bruneian film industry and its viable collaboration with the tourism industry in Brunei.

Interview data were coded and then analyzed using Nvivo software to examine key themes from interviewers. Limitations of research should also be acknowledged. It is recognized that only a small number of interviews were undertaken and this might be an issue of representativeness of our sample. Furthermore, the purposive sampling used in this study are individuals with an identified interest in film and travel which could be considered as biased. Nonetheless, random sampling of the population would have been unsuitable for this study as there might be higher chances of getting individuals with no interest in film nor travelling. Moreover, given the small number of film directors in Brunei, this study has almost covered and interviewed most of them. The qualitative responses are relevant and the key people in the film industry have provided rich and comprehensive data for this study. 


\section{Findings/Analysis - Interviews and Survey}

In this section, some of the key results will be discussed and analyzed. The results show the current issues of Brunei's creative or film industry from the perception of local film producers and also how genre or storyline affects viewers' perceptions of the destination in a film. Results also show that film plays a significant role as it can trigger and motivate tourists to visit the locations portrayed in a film.

A total of 201 questionnaires and 18 in-depth interviews were carried out in this study. The age distribution of respondents were mostly between 20-29 years and 30-39 years category. These respondents stated film or movie viewing as one of their significant pastime activity, where the majority of them watch films at home at least 2-3 times a week. In addition, most of the respondents go to cinema at least once or twice a month, mainly watching Hollywood blockbuster movies, among which comedy, horror and action films are their most preferred genres. All respondents express their interests in international films while more than half of them also express their interests in local films. Furthermore, $85 \%$ of the respondents have strong indication in travelling and have been on an international trip over the last 12 months for a short getaway (see Table 1). The majority of them express excitement in travelling and are eager to look for new experiences during their trip. One of the main objectives of this paper is to examine whether film motivates tourist to visit the locations or places portrayed in a film and whether filming in different locations has different impacts on tourist's decision making. Furthermore, this paper attempts to explore whether the film industry plays a part in shaping the perception of a destination in the hope of getting more in-depth knowledge on the relationship between film and tourism sectors. This exploration has been done by asking informants through questionnaires and interviews.

Table 1: Demographic Profile of Respondents

\begin{tabular}{|l|l|}
\hline Description & Number of Respondents \\
\hline Age: & 3 \\
Under 20 & 93 \\
$20-29$ & 95 \\
$30-39$ & 6 \\
$40-49$ & 4 \\
$50-59$ & \\
\hline How often do they watch film and TV & \\
series at home? & 17 \\
Every day of a week & 92 \\
3 times a week & \\
\hline
\end{tabular}




\begin{tabular}{|l|l|}
\hline 2 times a week & 87 \\
Others & 5 \\
\hline How often do they visit cinema? & \\
Once a month & 75 \\
Twice a month & 89 \\
Thrice a month & 30 \\
Others & 7 \\
\hline Preference of film genre: & Respondents can choose more than one \\
& option \\
Comedy & 125 \\
Drama & 72 \\
Horror & 91 \\
Musical & 10 \\
Action & 87 \\
\hline Indication of interest to travel after & \\
watching a movie: & \\
Yes & 194 \\
No & 7 \\
\hline Interest in film type: & Respondents can choose more than one \\
International & 201 \\
Bruneian & 130 \\
\hline Respondents who watch Bruneian & Respondents can choose more than one \\
films & \\
Yasmine (2014) & 177 \\
Ada apa dengan Rina (2013) & 58 \\
Ada apa dengan Rina 2 (2017) & 72 \\
Hari Minggu yang Ke-empat (2018) & 102 \\
\hline & \\
\hline
\end{tabular}

When examining whether watching film motivates people to visit the locations portrayed in a film, a diverse range of responses were given both through survey and interviews. Informants were asked for their reasons why they had visited a film location. $63 \%$ of informants expressed that had visited places shown in films. Various locations were mentioned such as Winter Sonata in Korea, Harry Potter in the UK, The Lord of the Rings in New Zealand, Indiana Jones in Jordan, The Beach in Khao Yai Thailand; Eat Pray Love in Bali as well as How I Met Your Mother, an American TV series in the US. The reason for visiting such locations is because they are already part of their holiday destinations, thus going to the film locations will add another valuable experience for their trips. As two informants recount: 
We are already at the destination and visiting the film location will tick off another place in my bucket list. (Informant 2)

I visited the film location, so I can share my visits online like in Instagram to encourage other people to visit as well. There is this sense of satisfaction where you are the only one among your friends who have visited a place filmed in a popular series. (Informant 3)

Another $34 \%$ of informants expressed that they were genuinely intrigued by the production set and wanted to experience and see the location in real life and $64.8 \%$ expressed a connection when they visited a place related to the movie.

I wanted to see how the movie was produced and wanted to relive the moment and that was shown in the TV series. (Informant 1)

I can feel the romance while visiting Nami Island in Korea and everyone was imitating the bicycle scene and the log scene by Choi Ji Woo and Bae Yong Joon in Winter Sonata. (Informant 4)

What was interesting in the findings was, however, the film-induced tourism motivation by international films. The majority of the informants were motivated to visit the film locations through international films. Nonetheless, there was little motivation for the Bruneian informants to visit the locations portrayed in a Bruneian film when discussing about local film productions in Brunei. Although the majority of the informants watched Yasmine, a locally produced film, none of the local informants were triggered or motivated to visit any of the local scenes in the film. There were only some interests to visit local locations expressed by international visitors or foreigners such as expatriates. The most popular Bruneian film among the informants are Yasmine (2014), followed by Hari Minggu yang Ke-empat (2018), Ada apa dengan Rina 2 (2017) and Ada apa dengan Rina (2013). Informants were asked for reasons why Bruneian films did not spark an interest in visiting locations in the films.

Brunei is such a small country. I suppose the thought of being so near to everything makes people put it off easily. Since it is always there, we can visit anytime. (Informant 1) 
Most of the locations are not advertised to the general public and we are unsure if it is open for public to visit. Like the silat place in Yasmine- I am unsure where that is and whether we are allowed to visit. (Informant 5)

Besides, the infancy stage of the film industry in Brunei is reflected in the findings of this study. There are a handful of domestic films and only half of the informants have indicated strong interest of them in comparison to international films. The Bruneian domestic films portraying Bruneian cultures and conveying cultural values are slowly progressing but not commercially viable yet.

Informants were also asked if filming in different locations has different impacts on their decision in visiting the film portrayed locations. $85 \%$ of them indicated that location matters and shapes their perceptions of the destination. It helps tourists, both domestic and international, to evaluate if the destination is worth visiting. This is, however, inextricably linked to the genre and storyline of the film. The majority of the movie producers or actors interviewed think that film plays a part in shaping the perception of a destination.

While portraying Brunei as a destination, selection of shooting place plays a role and it will make consumer remember how Brunei is. This is part of marketing and exposure. (Informant 6 - Producer)

However, producers also emphasized that the genre of the movie plays a huge role in selecting film locations.

If we are filming a documentary, the inclusion of iconic landmarks in Brunei such as the Sultan Omar Ali Saifuddin (SOAS) mosque will portray Brunei as an Islamic location. Similarly, filming in Temburong will give Brunei a more Eco resort destination and a combination of all will give an overview of Brunei as a destination. (Informant 8- Producer)

If we are filming horror movie, we would not necessarily include iconic landmarks as it just does not go with the storyline. (Informant 7Producer)

In addition, majority of the tourists expressed that the genre of a film does not determine the image of the destination. As an informant shared, "I am a huge fan of horror and I love to watch Thailand horror movies. This does not mean that I will perceive Thailand is a horror destination" (Informant 10 - Tourist). Although informants indicated the importance of location whilst filming, the inclusion of 
certain locations depends on the genre or storyline of a film. The genre of a film will, however, not resonate with the image of the destination.

Informants were also asked to rank the importance of the components for a movie. The inclusion of good storyline ranks the highest, followed by constant collaboration with regional or international industry, inclusion of international casts and inclusion of local culture and attraction. The results of local film producers interviewed are in agreement with the above questionnaires.

Ada apa dengan Rina 2 is a film project collaborated with the Laos film production which highlights both countries lifestyle. It has been doing extremely well as by collaborating we are doubling our audiences, our budget and our creativity. (Informant 8 - Producer)

"Involving the international cast will be a win-win situation as it gives a helping hand to boost Brunei film industry which is still at its infancy. (Informant 11- Producer)

In addition, Informant 9 states, "Exposure is the key! Yasmine the movie was released regionally to other Malay speaking countries like Malaysia and Indonesia. The outcome was one of the most successful local movie in Brunei and won the Asian film in Neuchatel Switzerland in 2014."

Ranking the components of the movie provide an overview of possible reasons to know what attract people to travel to a film location. $87 \%$ of the informants agreed that language is never seen as a barrier due to the availability of subtitles and dubbing. Involving international or regional cast gives a stepping stone for the local film industry to attract foreign investors to collaborate and engage with other film producers.

All Bruneian producers interviewed have recognized the link between tourism and film. As one of them states, "When you make a film, you are promoting the country. It is linked to an extent. Hollywood became America and Bollywood became India!" (Informant 12). 70\% of the informants mentioned the need to expose Brunei as a location and get foreign films made in Brunei. Selling and opening up locations to foreign investors is not a new concept as destination management organizations are working together with film commissioners to attract producers to film in their locations. England is one of the example attracting 28 million visitors each year after viewers worldwide see the country on screen (Kim, Agusa, Lee, \& Chon, 2008). Visit Britain program has made collaboration with India to use UK as a location for Bollywood movies. Furthermore, Singapore Tourism Board has launched The Film in Singapore Scheme (FSS) aiming to attract 
international film-makers to shoot in Singapore (Rewtrakunphaiboon, 2009). The most recent successful case is Crazy Rich Asian (2018) - an American romantic comedy-drama has brought the best promotion to Singapore (Badalge, 2018). Therefore, collaboration with production companies in neighboring states or internationally to reach for more opportunities, sponsorship and audiences was repeatedly mentioned by Bruneian film producers.

Table 2: List of Informants

\begin{tabular}{|c|c|c|c|}
\hline Informants & Description & $\begin{array}{l}\text { Duration of } \\
\text { Interview }\end{array}$ & Nationality \\
\hline Informant 1 & Local & 45 mins & Bruneian \\
\hline Informant 2 & Tourist & 42 mins & Japanese \\
\hline Informant 3 & $\begin{array}{c}\text { Social media } \\
\text { influencer }\end{array}$ & $1 \mathrm{hr} 23$ mins & Bruneian \\
\hline Informant 4 & $\begin{array}{c}\text { Local movie } \\
\text { enthusiast/ creative } \\
\text { industry }\end{array}$ & 1 hour & Bruneian \\
\hline Informant 5 & Local & 35 mins & Bruneian \\
\hline Informant 6 & Producer & $1 \mathrm{hr} 45$ mins & Bruneian \\
\hline Informant 7 & Producer & 2 hours & Bruneian \\
\hline Informant 8 & Producer & 1 hour 5 mins & Bruneian \\
\hline Informant 9 & Producer & 45 mins & Bruneian \\
\hline Informant 10 & Tourist & 20 mins & Vietnamese \\
\hline Informant 11 & Producer & 55 mins & Bruneian \\
\hline Informant 12 & Creative writer & $1 \mathrm{hr} 21 \mathrm{mins}$ & Bruneian \\
\hline Informant 13 & Director & 50 mins & Bruneian \\
\hline Informant 14 & Director/producer & 1 hour 20 mins & Bruneian \\
\hline Informant 15 & Writer & $1 \mathrm{hr}$ & Bruneian \\
\hline Informant 16 & $\begin{array}{c}\text { Thailand exchange } \\
\text { student }\end{array}$ & 45 mins & Thailand \\
\hline Informant 17 & Tourist & 25 mins & Singaporean \\
\hline Informant 18 & Tourist & 20 mins & British \\
\hline
\end{tabular}

\section{Textual Analysis - Potential of Film-induced Tourism in Brunei}

On October 23, 2018, Brunei's first feature movie Gema Dari Menara (1968) just celebrated its golden jubilee with an exclusive re-screening in Arena Cineplex of Seri Q-lap Mall, followed by a weeklong re-screenings of the movie in White 
Screen Cinema near Jalan Muara (Hab, 2018). All the re-screenings for this "hidden gem" of Brunei cinema have been sold out through pre-purchased tickets without any promotion effort.

Retrospectively, long regarded as "a time capsule of Brunei's lost pop history" (Espina, 2018, p. 70), Gema Dari Menara shows us some touristic trace and lens of the traditional kampong landscape. Besides, there are a lot of "touristy shots" of the main characters driving across the capital city to the expanded oil fields presumably in Seria (Espina, 2018, p. 69). Such sequences of tracking shots captured from inside a driving vehicle display the historical, touristic Kampong Ayer with the famous, old Mosque in the background, alongside other kampong settings, and beautiful beachside sceneries.

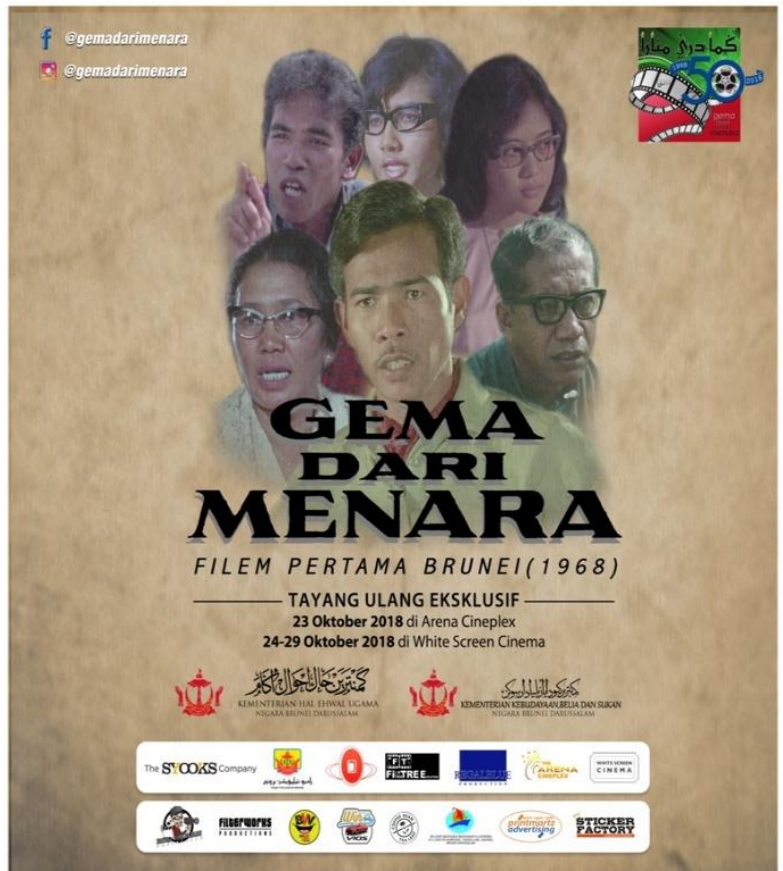

Figure 1: Re-screening poster for Brunei's first feature film Gema Dari Menara (1968). Image courtesy of White Screen Cinema in Brunei

As Espina notes, “The film's visuals celebrate the late 1960s Brunei's oilbought wealth and flaunt the newly-minted urban structures and monuments of the time". Espina continues, "However, the traditional kampong remains the place where the characters retreat upon finding themselves in dire straits, and it is here, in this humbled setting, where they redeem themselves through religion and strengthened familial tie" (2018, p. 69). The characterization and storyline of Gema 
Dari Menara make it conveniently fall into the family drama genre, which is one of the preferred film genres for Bruneians confirmed by the finding results (72 out of 201 respondents) of our questionnaire. If the film's signature locations, e.g. the kampong settings that unfold the family drama, the beachside groves that hold the sunny picnic, even the jailhouse in Jerudong that incarcerates the "depraved couple", being re-located, retrieved and then repackaged by a local tourist agency, they could become a new niche for some Bruneian domestic tourists, following the heated re-screenings of Gema Dari Menara.

For the emerging Bruneian film industry, there is another celebratory news coming back from Korea recently. A local filmmaker based in Tutong, Abdul Zainidi, has just won the prestigious Purin Award for his short film The Worm and the Widow at the Busan Asian Film School (AFIS); earlier in July this year, the film already won the Network of Asian Fantastic Films' top prize during the 22 ${ }^{\text {nd }}$ Bucheon International Fantastic Film Festival (BiFan) in Korea. It is also reported that The Worm and the Widow "is the first Bruneian film to feature Tutong and sign languages" (Kon, 2018).

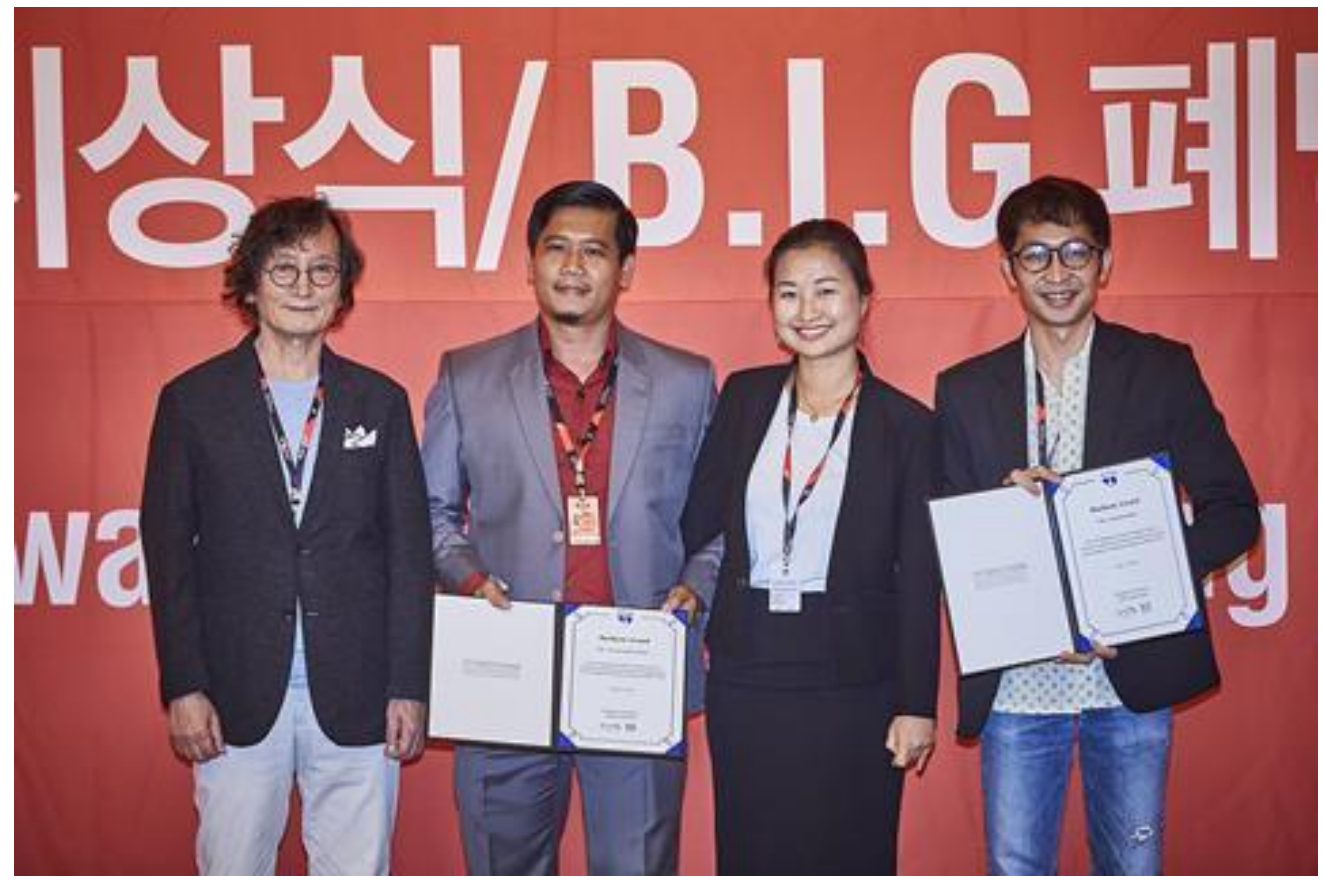

Figure 2: Abdul Zainidi (right) receives the top award - Bucheon Award at 2018 Network of Asian Fantastic Films (NAFF) in the 22nd Bucheon International Film Festival in South Korea. Image courtesy of Jean Noh 
This award to Zainidi's above film is not only inspiring news for the Bruneian film industry but also an important promotion opportunity for the slow development of Tutong tourism. Especially considering this prestigious Asian film award will be instrumental in boosting the film's future international distribution and recognition, it will draw more international and domestic audiences, potentially resulting in Tutong being a visiting destination for more tourists and a shooting location for more films.

As an essential figure representing the younger generation filmmakers in Brunei, Zainidi has earned fame with his short horror docu-fiction trilogy Vanishing Children (2015), More Vanishing Children (2016), and Still Vanishing Children (2017). In a matter of fact, all the three horror shorts were also shot in Tutong and based on the events of "real missing people in Brunei" (IMDb website). According to the results of our questionnaire, the majority of the respondents expressed that film genre does not determine the image of the touristic destination. This is especially true for the horror/scary genre when tourists make their decisions whether to visit a filming location in a horror movie, as one surveyed tourist replies, "I am a huge fan of horror and I love to watch Thailand horror movies. This does not mean that I will perceive Thailand is a horror destination" (Informant 10).

Indeed, there are multiple and complex motivations for film tourists to decide to visit a particular destination based on an array of studies targeting at different groups of tourists in terms of age, education, cultural background and nationality disparity (Connell, 2012). Other studies also indicate that the "promise of risk and curiosity about the exotic nature of unknown and unfamiliar places and peoples has long motivated people to travel" (Douglas, 1997 \& Mantobani, 1997, quoted in Korstanje \& Olsen, 2011). Citing multiple studies, Korstanje and Olsen (2011) further point out whether deciding to travel to unfamiliar or risky destinations, where most horror movies set their main storylines and unfold the horror schemes, is related to the personality traits and the travel styles of those who make the decisions. As Lepp and Gibson (2008) note, "people who are sensation seekers tend to travel more internationally to places labelled more risky than those who are not sensation seeker" (Korstanje \& Olsen, 2011). Although the discussion context of Korstanje and Olsen is about the risk and safety discourses of American international travelers in post 9/11 horror movies, their above discussions endorse the conclusion we have drawn earlier from our questionnaire. Films in horror genre neither resonate with the image of the destination portrayed in them nor necessarily influence the decision making of the film tourists in a negative way. 
That is why there have long existed the concepts-based film location tour in some haunted "ghost houses" located in some Southern American cities, e.g. Savannah, GA and Charleston, SC. These cities are well-known with their typical Southern cityscape and architectures, attracting a lot of Hollywood productions, including many horror films, to intentionally set their main scenes and storylines in such Southern old towns when the films' main narratives fit. Therefore, a number of filming locations are scattered adjacent to historical buildings in the downtown districts for cult fan-bases of some horror films to explore the film settings and experience the "real" feelings of the fictional characters in the fictional circumstances. This sort of customized group tour usually takes place during night time and a group of tourists gather up at a particular assembly point before going together to visit a number of 'haunted' film locations and encounter the grotesque, haunting aura derived from the original horror film.

Following the distribution of Zainidi's upcoming, award-winning film The Worm and the Widow, the local travel agencies in Tutong may use above "ghost house" concept, for example, launching a Tutong Horror Movie Sets Tour, by packaging all the shooting locations of Zainidi's previous horror docu-fiction shorts, to boost more tourist visitation and overnight stay in Tutong. The preference numbers of horror genre (the second most behind the numbers for comedy genre) from the respondents of our questionnaire and the successful "ghost house" tours in America suggest a potential effectiveness of such strategy to attract both Bruneian domestic and international tourists. It just hinges on the timing of launching the tour programs, perhaps following the distribution of Zainidi's new award-winning film may be a viable opportunity. It also depends on how the local tourist organizations, the local filmmaker, and Tutong local government work together cooperatively to initiate and promote the touring program. In this respect, the exemplary cases of Matamata, New Zealand and Ystad, Sweden - two small towns that have successfully transformed into, and sustainably remained, the popular film/TV-induced tourist destinations - are both worth paying attention to and investigating (Leotta, 2011; Waade, 2016).

As mentioned earlier, horror genre is only the second preference behind comedy genre, which earns the highest number 125 out of 201 respondents in our questionnaire. It is not a surprise that following the most watched Bruneian movie Yasmine (2014), which is an action drama, other popular Bruneian local productions, i.e. Hari Minggu yang Ke-empat (2018), Ada apa dengan Rina 2 (Rina 2, 2017) and Ada apa dengan Rina (2013) are all comedies. The global box-office sensation Crazy Rich Asian (2018), which is a mixed genre of romance and comedy - the so-called Rom-Com, is also a big hit in Brunei. Its success of promoting the Singapore tourism, as analyzed in above sections, shows the importance of 
government policymaking and tourist agency initiatives in working with international collaboration for both film productions in, and touristic promotion of, Singapore (Badalge, 2018). Yasmine for instance, by casting a mix of Indonesian and Bruneian talents, it has been able to release in the neighboring Malay speaking countries, e.g. Malaysia and Indonesia to become the most popular Bruneian movie so far.

For another instance, as a co-production of Brunei and one of the ASEAN states Lao, Rina 2 not only "doubles the audience" in two countries but also gives Brunei a great opportunity to demonstratively promote its most important ecotourism resource - Ulu Temburong National Park. The Tourism Development Department (TDD) immediately realized the potentiality of boosting this conceptual destination of ecotourism in Brunei to the globe when having a conversation with the filmmakers of Rina 2, so TDD brightly agreed to sponsor the crew two filming trips to the locations in Ulu Temburong National Park.

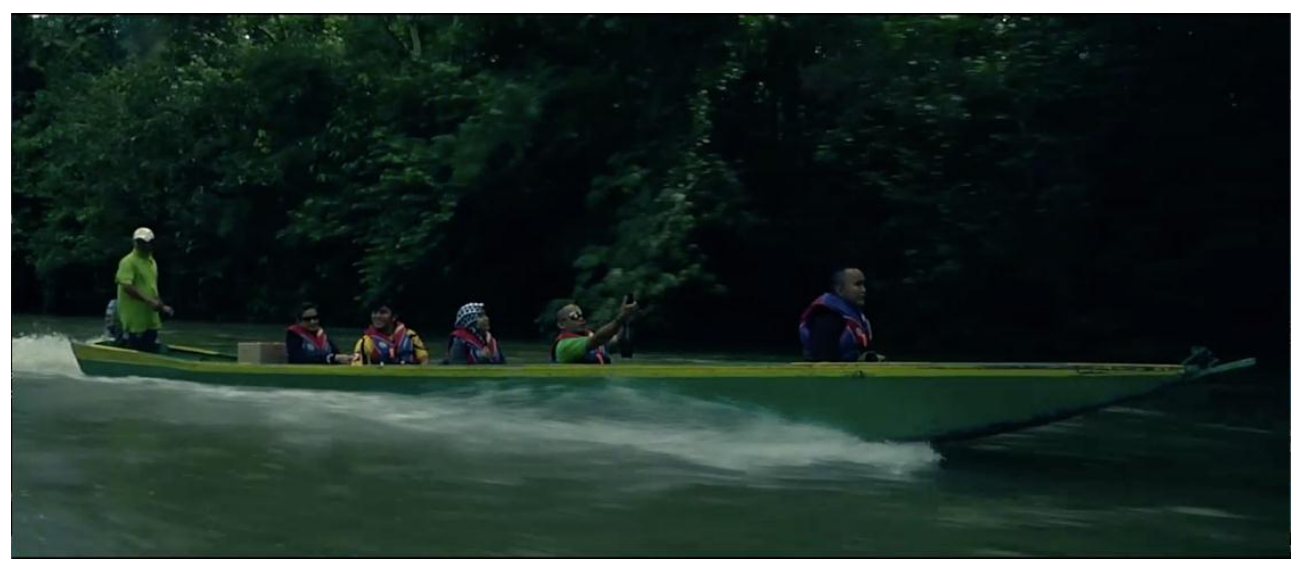

Figure 3. Ada apa dengan Rina 2 (Dir. Harlif Hj Mohamad, 2017). Image courtesy of Nurain Abdullah, producer of Ada apa dengan Rina 2

According to the producer of Rina 2, "If our film goes to cinema or film festivals abroad, we want to show Brunei. So we talked to the Tourism Development Department, then we got sponsorship (from TDD) for the trips to Temburong...for the crew and actors, by boat and go up the cableway to see the Brunei forest" (Interview with Nurain Abdullah, April 26, 2018). Rina 2 excellently fuses the display of the beautiful Temburong rainforest sceneries into the romantic storyline and the development of character relationship. TDD - the Brunei government agency, on the one hand, facilitates the local filmmakers to achieve their creative attempt; on the other hand, it gets rewarded a tremendous self- 
promotion opportunity to demonstrate their quality tourist products internationally when the film is distributed in Lao, other Southeast Asian countries and beyond.

Although the genuine effect of Rina 2 initiative on Brunei's tourist promotion is still unclear and needs more studies to elaborate, the successful filminduced tourist cases e.g. TLOTR and Matamata, New Zealand, Wallander and Ystad, Sweden, as well as the most recent Crazy Rich Asian and Singapore, are all proven beneficial from the collaboration between local production talents, national and local government policy incentives, and local tourist organizations.

\section{Conclusion}

The influence of film in portraying destination image to induce tourist arrivals is not a new phenomenon. This paper provides exploratory information of filminduced tourism in Brunei and calls for an invitation for more empirical studies in this area. We have discussed possible relationship between film and tourism industry relating to tourist behaviours. It has highlighted the potentiality of using film to effectively market Brunei as a tourist destination. The results show a high percentage of individuals who have expressed emotional connections with the location shown in films. Nonetheless, only a small percentage of them are willing to intentionally travel to that particular destination due to a movie. Respondents are normally intrigued with the set or production locations and also willing to visit if they happen to be at the destination. This, therefore, shows that film is a secondary motivator for Bruneians to visit a film location. It serves as a complement product for a destination which enhances its exposure while showcasing its culture and heritage through moving images. It has triggered a strong interest in travelling. However, it does not serve as a primary motivator for visiting a film portrayed location. This is evident in the results showing some interest by foreigners/expatriates to visit local places shown in local films and low motivation for Bruneians to visit the portrayed location in domestic films. Reasons such as "places not open to public", "unsure of where the portrayed location is" are all signs of ill-equipped and unpreparedness to take advantage of the film marketing strategies. Planning and working together with relevant key stakeholders needs to take place to properly strategize Brunei as a destination that is commercially viable. Some producers have already done this interviewed stating collaboration with regional producers and government to increase exposure for targeted audiences.

Additionally, the results have also indicated that location matters and shapes the perception of the destination which helps tourists evaluate if the 
destination is worth visiting. Nonetheless, the inclusion of certain location depends on the genre or storyline of the film. The genre of a film, however, does not resonate with the image of the destination. This is shown in the explanation of horror genre above. Results also highlight the importance of collaboration with neighboring countries, e.g. Malaysia and Indonesia, our two neighbors on Borneo Island, and other ASEAN states, for both film production and touristic promotion purposes. Moreover, involving international or regional cast gives a stepping stone for local film industry to attract foreign investors to collaborate and engage with other film producers. Opening up locations to foreign productions is not a new concept worldwide as destination management organizations are working together with film commissioners to attract international productions to film in their domestic locations. The successful film-induced tourist cases, e.g. TLOTR and Matamata, New Zealand, Wallander and Ystad, Sweden, alongside the most recent Crazy Rich Asian and Singapore, are all proven beneficial from the collaboration between local production talents, national and local government policy incentives, and local tourist agencies. Perhaps it is time for the Bruneian travel organizations to step up and join the force with Bruneian creative talents and municipal/national governments to nurture Brunei tourism to a more mature and sustainable extent by launching some film location or film concept-related touring programs and products.

\section{Acknowledgment}

The authors would like to express their gratitude to the University Conference Grants from Universiti Brunei Darussalam.

\section{References}

Badalge, K. (2018, August 28). Singapore: 'We are the crazy rich Asians'. Asia Times Website. Retrieved October 2, 2018, from http://www.atimes.com/article/singapore-we-are-the-crazy-rich-asians/

Connell, J. (2012). Film tourism: Evolution, progress and prospects. Tourism Management, 33(5), 1007-1029.

Douglas, N. (1997) The fearful and the fanciful: Early tourists perception of Western Melanesia. The Journal of Tourism Studies, 8(1), 52-60. 
Espina, M. (2018). Gema Dari Menara/Echoes from the minaret: A conversation with Mervin Espina about the lost cinema of Brunei. Academia.edu. Retrieved October 31, 2108, from http://www.academia.edu/11363993/Gema_Dari_Menara_Echoes_from_t he_Minaret_A_Conversation_about_the_Lost_Cinema_of_Brunei

Grihault, N. (2003). Film tourism - the global picture. Travel and Tourism Analyst, $5,1-22$.

Hab, F. (2018, October 21). First Brunei movie celebrates golden jubilee. Borneo Bulletin, p. 4.

Hod, I. (2018, August 30). 'Crazy rich Asians' effect: Singapore travel searches spike since movie opened. The Wrap Website. Retrieved October 3, 2018, from https://www.thewrap.com/crazy-rich-asians-prompts-triple-digit spike-travel-searches-Singapore/

Hudson, S., \& Ritchie, J. R. B. (2006). Film tourism and destination marketing: The case of Captain Corelli's mandolin. Journal of Vacation Marketing, 12(3), 256268.

Kim, J., \& Ritchie, J. R. B. (2014). Cross-cultural validation of a memorable tourism experience scale (MTES). Journal of Travel Research, 53(3), 323-335.

Kim, S., Agusa, J., Lee, H. \& Chon, K. (2008), Effects of Korean television dramas on the flow of Japanese tourists. Tourism Management, 28(5), 1340-1353.

King, V. (2017). Emerging tourism and tourism studies in southeast Asia (Working Paper No. 35). Bandar Seri Begawan: Institute of Asian Studies, Universiti Brunei Darussalam.

Kon, J. (2018, October 23). Local film director wins prestigious purin award. Borneo Bulletin, Homepage p. 7.

Korstanje, M., \& Olsen, D. (2011). The discourse of risk in horror movies post 9/11: Hospitality and hostility in perspective. International Journal of Tourism Anthropology, X(Y), 1-14.

Leotta, A. (2011). Touring the screen: Tourism and New Zealand film geographies. London: Intellect Books.

Lepp, A., \& Gibson, H. (2008). Sensation seeking and tourism: Tourist role, perception of risk and destination choice. Tourism Management, 29(1), 740750 .

Mantobani, J. M. (1997) Las Raíces ocultas. Mar del Plata y el problema de la creación de lospueblos balnearios del sudeste de la Provincia de Buenos Aires a fines de siglo XIX. In F. Cacopardo (Ed.), Mar del Plata, Ciudad e Historia (pp.40-90). Buenos Aires: Alianza.

Othman, A. (2018, September 8). Brunei's tourist arrival growth is sea's 3rd fastest. Borneo Bulletin. Retrieved December 12, 2018, from 
https://borneobulletin.com.bn/bruneis-tourist-arrival-growth-is-seas3rd-fastest/

Park, S., \& Santos, C. A. (2017). Exploring the tourist experience: A sequential approach. Journal of Travel Research, 56(1), 16-27.

Prince, R. (2014, September 17). Friends coffee shop open to mark 20th anniversary of hit sitcom. The Telegraph. Retrieved October 2, 2018, from https://www.telegraph.co.uk/news/worldnews/northamerica/usa/11102 423/Friends-coffee-shop-opens-to-mark-20th-anniversary-of-hitsitcom.html

Rewtrakunphaiboon, W. (2009). Film-induced tourism: Inventing a vacation to a location. BU Academic Review, 8(1), 33-42.

Riley, R., Baker, D., \& Van Doren, C. S. (1998). Movie induced tourism. Annals of Tourism Research, 25(4), 919-935.

Scott, N., Laws, E. \& Boksberger, P. (Eds). (2010). Marketing of tourism experiences. London: Routledge.

Waade, A. (2016). Nordic noir tourism and television landscapes: In the footsteps of kurt wallander and saga noren. Scandinavica, 55(1), 41-65.

\section{Film databases}

Ada apa dengan Rina (2013):

https://www.imdb.com/title/tt2829176/?ref_=fn_al_tt_1

Yasmine (2014):

https://www.imdb.com/title/tt3320232/?ref_=fn_al_tt_1

Ada apa dengan Rina 2 (2017):

https://www.imdb.com/title/tt5950590/?ref_=fn_tt_tt_1

Still Vanishing Children (2017):

https://www.imdb.com/title/tt7293292/

Hari Minggu yang Ke-empat (2018):

https://www.imdb.com/title/tt8686060/?ref_=nm_flmg_dr_1

Date of Received: 15 October $2018 \quad$ Date of Accepted: 15th December 2018 